\title{
VIEWS ON WORLDVIEWS: AN OVERVIEW OF THE USE OF THE TERM, WORLDVIEW, IN SELECTED THEOLOGICAL DISCOURSES
}

Ernst Conradie

Religion and Theology

University of the Western Cape

\begin{abstract}
This article explores the ways in which the term 'worldview' is used in five distinct contexts that shape the study of religion and also of Christian theology, namely neoCalvinism, the sociology of knowledge, discourse on religion and ecology, discourse on science and theology and African Traditional Religion. One text by one author is selected in each case to describe the distinct ways in which the term is used. This description suggests that the term is used in theological debates with very different connotations and also with very little cross-referencing - this can only cause confusion. On this basis a modest proposal is made as to what the notion of a worldview could entail, at least in the context of theological discourse.
\end{abstract}

Key Words: African Religion; Neo-Calvinism; Religion and Ecology; Science and Theology; Sociology of Knowledge; Worldviews

\section{Introduction}

There is consensus in the literature that the term 'worldview' (also spelt world view or world-view) is derived from Immanuel Kant's use of the term Weltanschauung in his Critique of Judgement, first published in 1790. Kant described the perceptive powers of the human mind to have an intuition of the world as a whole, indeed of the infinite. From this usage in Kant (who used it only once and did not attach much significance to it) the term evolved rather quickly and was eventually adopted in the social sciences, in philosophy, religious studies and theology alike (see Naugle 2009:6-7).

It would be an understatement to say that there is a conflicting plurality of views on what a worldview entails. It may be used as a rough synonym for (scientific) cosmology, (philosophical) ontology, religiously-infused belief systems regarding God, the world and humanity, religious perspectives on social priorities, social philosophy or to describe the social construction of reality. One may say that its meaning depends on what the term 'world' is taken to refer to.

Given this conflicting plurality it may not be very fruitful to seek to standardise the meaning of the term. It is necessary to add that a view of the world as a whole is of course impossible. For example, one cannot see the whole of the University of the Western Cape. Each of us experiences only tiny fragments of that whole and then constructs an image of what constitutes the whole by using the acronym 'UWC'. This applies even more of terms such as 'Cape Town', 'South Africa' or 'the earth' that are commonly used. Where can one then find a worldview? The most significant feature of a worldview is that one cannot view 'the world' and that one is typically unaware of viewing it in a particular way. 
Yet, a view of the world may be constructed from within this world even though one cannot view 'the world'. The need to recognise the invisible is widely recognised in the biblical roots of Christianity, in Greek philosophy, Patristic Christianity and in indigenous African culture alike. It also forms part of common human experience. After all, one cannot see someone's personality, friendship, love, a university, a country or indeed the world as such. One may watch soccer but one cannot see 'soccer'. One may adopt a worldview but one cannot view the world as it were at a distance if one necessarily participates within it.

In this contribution I will suggest that the term is used in various distinct discourses that influence the study of religion and theology. Within these discourses the use of the term is sufficiently similar so that communication is possible. Between these discourses the use of the term is not necessarily incommensurable but it is certainly rather confusing. I will outline especially five such discourses, namely neo-Calvinism, current dialogue on science and theology, academic debates on African religion, discourse on 'religion and ecology' and in the sociology of knowledge. I will select one more or less representative book where the term worldview is used, i.e. (in chronological sequence given the date of first publication) Abraham Kuyper's The Stone-lectures (1899), Peter Berger's The Sacred Canopy (1967). Mary Evelyn Tucker \& John Grim's edited volume on Worldviews and Ecology (1994), George Ellis and Nancey Murphy's book On the Moral Nature of the Universe (1996) and Laurenti Magesa's African Religion: The Moral Traditions of Abundant Life (1997). In each case I will offer a brief description of how the term worldview is understood.

In this contribution I will merely juxtapose these five discourses where the term worldview is used. My aim is merely to aid communication between these discourses given an obvious lack of cross-referencing between such uses of the term. I will offer a modest proposal by indicating some of the overlapping connotations of the term.

In a subsequent contribution I hope to explore the position of Herman Bavinck with specific reference to his Stone lecturers entitled The Philosophy of Revelation (1909) in more detail. Although this work forms the basis of neo-Calvinist discourse on worldviews which had a disastrous influence in the South African context, it is in my view fundamentally misunderstood. For this contribution I will therefore focus on his colleague Abraham Kuyper's Stone lectures (1898).

\section{Neo-Calvinist Discourse on Worldviews: Abraham Kuyper's Stone Lectures (1898)}

In the first of his Stone lectures of 1898 Abraham Kuyper, the Dutch theologian, politician, newspaper editor and founder of the Free University in Amsterdam, describes Calvinism as a 'life-system'. Kuyper first explores the meaning of the label 'Calvinism' and suggests that it is best understood as a form of religion that is born from its specific religious consciousness which gives rise to a particular theology, a church order, an interpretation of the moral world order with implications for political and social life, including the state, art and science (Kuyper 1931:17). These themes are covered in each of the other lectures. In the first lecture he continues to argue that the underlying orientation of such a form of religion may be understood as a 'life-system'. This orientation is expressed in religious beliefs around three fundamental relations, namely our relation with God, our relation to other human beings and our relation to the world (1931:19). Kuyper then discusses (and boldly praises) a Calvinist view on these three fundamental relations in comparison with other life- 
systems, namely paganism, Islam, Romanism and modernism, with occasional references to Buddhism, Lutheranism and Anabaptism.

His views in this regard need not concern us here although it should be added that Kuyper's bold claims about religious, cultural and racial (!) superiority would be highly contested a century or so later. Suffice it to say that for Calvinism the world is seen as God's fallen creation. As a result of 'common grace' that restrains the impact of the curse, believers are called to serve God in the world - instead of a monastic evasion of the world or a pagan over-estimation of the world. For Kuyper this meant that every square inch of society is the terrain in which the reign of God has to be established. This yielded a theocratic ideal through Christian political parties (Kuyper was the leader of the AntiRevolutionary Party in the Netherlands), but certainly not any form of ecclesiocracy. In extreme form this suggested for some of his followers the need for Christian biology and even Christian mathematics since a worldview supposedly shapes how one looks at anything in the world while nothing falls outside the scope of religious beliefs.

Kuyper's views shaped the further development of neo-Calvinism in the Netherlands, in the USA and also in South Africa. The relevance of a reformed understanding of the Christian faith for society is operationalised in terms of a 'Christian/reformed worldview' by South African exponents of neo-Calvinism, especially through the long-standing research initiatives of the Institute for Reformation Studies located at the Potchefstroom campus of what is now North-West University. This institute explicitly builds on the legacy of Kuyper, Herman Bavinck, Herman Dooyeweerd and others. The term 'worldview' is used as a rough synonym for Weltanschauung or lewens- en wêreldbeskouing, i.e. a comprehensive interpretation framework that governs one's views on anything (see Wolters 2005). This provided the philosophical apparatus not only to implement Christian (national) education but also to structure the South African society according to this brand of Calvinism - with disastrous consequences.

In hindsight this use of the term worldview is rather peculiar. It undoubtedly helps to indicate how religious traditions (also within Christianity) structure the ways their adherents look at the world in quite different ways. Such views on (or perceptions of) the world shape the attitudes, priorities and praxis of adherents. This is based on an articulation of the social significance of belief systems. However, if the emphasis is here on a view of the world, in what way is this indeed a view of the world? Does it actually help one to see things that would otherwise have been missed? How is this notion of a worldview shaped by scientific data and by social analysis? Or does the religious zeal to transform the world in every square inch of society reveal world-blinkers or even world-blindness instead of a worldview? If the focus here is on viewing the world, it seems that one is invited to look at the viewing instead of at the world.

In my view the problem is that it becomes rather difficult to know in what way this use of the term worldview differs from a Calvinist understanding of doctrine (a form of systematic theology) or a form of social ethics that indicates social priorities. Moreover, the biblical roots of such a worldview beg questions about the evolution of such a life-system. Can biblical 'principles' serve as 'norms' for any worldview? Can a worldview be derived from the Bible or from the reformed tradition? The question is therefore how this understanding of a 'reformed worldview' relates to a Christian understanding of the world (as discussed in systematic theology), the 'social construction of reality' (as a sociological term) and cosmology (understood as a comprehensive understanding of the world based on scientific evidence). If a Christian worldview is the same as a Christian view of the world, 
it is best discussed as a theme in systematic theology, namely by re-describing the world as the triune God's own beloved 'creation'. If not, how are sociological and scientific data to be incorporated in a Christian worldview? Clearly, Christian perspectives on the world underdetermine the available data so that such a worldview cannot be derived from biblical principles alone. Christian doctrine can hardly prescribe a cosmology and it would therefore be difficult to know what a Christian cosmology or (a) biblical worldview(s) could possibly mean. In the biblical roots of the Christian tradition one may find different cosmological assumptions.

Nevertheless, it is at least clear that the peculiar world-transformative impetus of Calvinism, operationalised in terms of a 'reformed worldview' may be understood in this light, sometimes for better (given the remarkable involvement of Calvinists in fields such as science, education, medicine and governance) but alas also for worse. The uneasy reception of such a neo-Calvinist understanding of the term worldview in North America has recently been explored in an insightful volume of reflections entitled After Worldview (Bonzo and Stevens 2009).

\section{Sociology of Knowledge: Peter Berger on the Sacred Canopy (1967)}

Sociologists often describe processes of social construction, for example the social construction of gender or masculinity. In social theory the role played by worldviews is described in terms of the social construction of reality itself. Peter Berger and Thomas Luckmann's treatise on the sociology of knowledge offers a classic example in this regard although they do not really use the term worldview. Berger and Luckmann (1966:26-27) actually argue that theoretical thought, ideas or Weltanschauungen are not that important in society. Only a limited group of people in any society engages in the construction of worldviews. To exaggerate the importance of theoretical thought is a natural failing of theorisers. Instead, the sociology of knowledge focuses on whatever passes for knowledge in everyday life, on common sense knowledge rather than on ideas. In order to understand such knowledge the social world inhabited by ordinary people becomes the focus of the sociology of knowledge. The term worldview is therefore best described as the outcome of the social construction of reality.

Berger and Luckmann describe the way in which a society integrates its life experiences, reconstructed history, behavioural patterns, language conventions, symbols and social institutions into a more or less coherent, meaningful whole. This is described as a process of 'world-construction' (see Berger 1967:3-28; Berger \& Luckmann 1967:63-109). They introduced the term 'symbolic universe' to indicate such a comprehensive framework, structured around a set of core symbols, which enables one to interpret any new experiences. They explain: "...all the sectors of the institutional order are integrated in an all-embracing frame of reference, which now constitutes a universe in the literal sense of the word, because all human experience can now be conceived of as taking place within it" (Berger \& Luckmann 1967:114).

The objectification of social reality is then internalised as objectively valid through a process of socialization that is described as 'world-maintenance': "Knowledge about society is thus a realization in the double sense of the word, in the sense of apprehending the objectivated social reality, and in the sense of ongoingly producing this reality" (Berger \& Luckmann 1966:84). The symbolic universe provides the lens through which all new experiences are interpreted. It sets parameters within which newcomers are included and 
socialised. It offers a prescribed nomos and ethos for a community. Within this definition of what counts as reality there is some room for differences of opinion, but no drastic change in terms of what counts as reality is possible without disrupting the bonds of community. Within the canopy provided by a symbolic universe dedication and loyalty are therefore expected and ritually secured (see Berger 1967:29-53).

Religion plays a crucial role world-construction and world-maintenance because it places a symbolic universe within a larger cosmic perspective and confers on it an absolute validity, described by Berger (1967) as a 'sacred canopy'. He says: "Religion legitimates social institutions by bestowing on them an ultimately valid ontological status, that is, by locating them within a sacred and cosmic frame of reference" (Berger 1967:33). The role of religion may therefore be understood in terms of the social construction of Ultimate Reality. This helps one to place the whole of reality within the even wider context of Ultimate Reality. Religion, unlike culture, therefore helps people to understand not only part of reality but the whole of reality and what may transcend reality as such.

A few further observations follow from these considerations: The social construction of reality and indeed of ultimate reality is a more or less inevitable and necessary process because humans need to understand anything within a larger interpretative framework. Religion can no longer offer an all-encompassing interpretative framework if it acknowledges the validity of other constructions of the ultimate. By definition a recognition of the validity of another construction of the ultimate next to my construction of the ultimate would imply that my construction no longer attempts to describe that which is ultimate. As Berger and Luckmann (1966:126) observe, "The appearance of an alternative symbolic universe poses a threat because its very existence demonstrates empirically that one's own universe is less than inevitable." In this sense even the word religions (in the plural) is problematic. Every one religion needs to offer a framework within which all other religions may be placed. Berger uses the term 'symbolic sub-universe' to describe the situation in which religious traditions find themselves where they no longer offer an interpretative framework for the whole of reality, but only one for family life, sexuality, personal self-fulfilment and so forth. When religion is restricted in this way, a new construction of the ultimate would typically emerge in such a situation. This is evident in the emergence of ideologies such as nationalism, civil religion, technocracy, hedonism and consumerism.

It may be noted that, in terms of this use of the term worldview, the tacit and often hidden assumptions of the social construction of reality are foregrounded. One's worldview is best described by others. By contrast, in neo-Calvinist discourse a worldview is adopted self-consciously and explicitly. It may also be noted that the cosmological parameters of the 'world' that is constructed hardly play a role here.

\section{Religion and Ecology: Tucker \& Grim's Volume on Worldviews and Ecology (1994)}

The intuition behind much of contemporary discourse on religion and ecology is that the roots of the environmental crisis are related to the emergence of a modernist worldview. This is not a comment on the birth of modern science associated with the names of Galileo, Newton and Darwin. Instead, the view of the world that is addressed here has to do with a philosophical understanding of the relationship between the human species and non-human nature and therefore with the place of humanity in the earth community. Modernist views in this regard are criticised as anthropocentric and indeed androcentric, as based on a logic of objectification and domination, and as all too rationalistic. 
In order to find an alternative worldview that can support and guide an environmental ethos and praxis premodern sources found in the world's religious traditions are explored and blended with the story of the universe as reconstructed on the basis of contemporary science. This blend may appear counter-intuitive but that may be precisely the genius of such discourse on religion and ecology. The full range of world religions is explored in order to recover the ecological wisdom that may have become lost as a result of the rise of modernity. Accordingly, the religious understanding of the place of humanity in nature is described under the rubric of 'religious worldviews'. The moral implications of such insights are then coded anew, especially through the principles of the Earth Charter that emphasise human respect for nature.

The problem in retrieving such religious wisdom is of course that the religions of the axial age are embedded in a cosmology that is no longer plausible. They may articulate symbols and archetypes that can challenge modern economic structures and can serve as a source of inspiration for an ecological ethos, but only if that can help us to make sense of the world in which we find ourselves. This is where a reconstruction of the story of the universe is employed, especially following the pioneering work of Teilhard de Chardin, Thomas Berry and Brian Swimme (see 1992). The intuition is that there is a clear ecological moral to this story. Humans are latecomers in the story of the evolution of life on earth. The human species pale into significance within a cosmic frame of reference. Yet the emergence of consciousness also suggests the recognition of human grandeur and significance.

On the basis of such insights Tucker and Grim (a husband and wife team) edited a volume entitled Worldviews and Ecology (1994). They were also instrumental in establishing a journal entitled Worldviews: Global Religions, Culture, and Ecology that has appeared since 1997. The edited volume includes an essay by Tu Wei-ming entitled 'Beyond the Enlightenment Mentality', an essay on a global environmental ethic by J Baird Callicot, nine essays on particular religious worldviews, and seven essays on contemporary ecological perspectives, including ones on emerging scientific paradigms, ecofeminism, deep ecology, process philosophy and then Thomas Berry's essay on ecological geography, Brian Swimme's essay on cosmogenesis and Larry Rasmussen's one on cosmology and ethics. This last essay captures the remarkable focus of the volume on the relationship between cosmology and ethics. As Rasmussen (1994:176) notes, humans are 'incorrigibly cosmic storytellers': "We are as a species storytellers who refuse to stop short of the cosmic story itself, despite (or because of?) its pretentious dimensions." He adds that ethics and cosmology are inextricable: without cosmologies we would literally not know what to do. He then explains: "Religious cosmologies cannot do what good science does, but they hold distinct advantages science does not. Because their language is mythic, they can tell of the end and purpose of existence without abstracting them from experience. Moreover, religious cosmologies characteristically trade in ultimates - ultimate origins, destiny, meaning, value. Science can venture close to these but cannot leap, as science, into the final interpretation of faith" (1994:177). The relationship between cosmology and ethics is therefore mediated by religious cosmologies that place what we otherwise know from science within an explanatory framework with ultimate scope by mythologising the ultimate significance of scientific insights.

One may say that the strength of such a use of the term worldviews is that the cosmological assumptions of religious belief systems and philosophical systems (e.g. modernity) are made explicit by describing the ethical (ecological) implications of such a way of viewing the world. However, the way in which science and belief are blended here 
(following Teilhard and Berry) begs the question how the use of different scientific paradigms in one extended religious tradition (notably Christianity) should be understood. There is clearly not just one biblical or Christian (or even reformed) worldview so that any such adjective may well be meaningless. If the term is to be used descriptively, it would have to articulate the tacit assumptions embedded in the social construction of reality.

\section{Science and theology: George Ellis and Nancey Murphy On the Moral Nature of the Universe (1996)}

In discourse on science and theology the term cosmology is widely used with reference to scientific attempts to develop an integrated understanding of the laws of nature. Our understanding of these laws of nature has been shaped by various scientific paradigms that continue to be influenced by philosophical assumptions. There is no physics without metaphysics since the mere existence and history of the universe continues to beg questions about its ultimate origins and telos. Moreover, these laws of nature describe realities that are inherently historical so that in physics, chemistry, geology, biology, zoology and psychology one can roughly identify a timeline for the first instantiation of a particular law of nature.

In their book with the provocative title On the Moral Nature of the Universe: Theology: Cosmology, and Ethics (1996) cosmologist George Ellis and philosopher Nancey Murphy seek to re-integrate scientific, philosophical and theological understandings of the world. They observe that ancient and medieval worldviews tended to provide links between the cosmic and the social order so that it structured what Stephen Toulmin (1990) aptly termed a 'cosmopolis'. In response to the disintegration of the medieval synthesis (arguably with disastrous consequences for the current moral order) they seek a reconstruction of a unified worldview by showing that a particular moral vision, namely an (Anabaptist) kenotic ethic, is supported by evidence from the natural and social sciences as well as by theological considerations (1996:1). This synthesis would relate a conception of the natural order to a conception of the moral order, of what the good life entails (1996:3). They maintain that the sciences are not value free and that ethics is tied to science but not reducible to it (1996:6).

They do so by suggesting a revised hierarchy of the sciences based on levels of complexity: from atoms to molecules to cells to multi-cellular organisms to central nervous systems to consciousness to self-consciousness (mind) to social systems (language, politics, economic systems) to an understanding of what the world ought to be (ethics) to discussions of what transcends the world as such (metaphysics and theology). They suggest that interactions between these levels of complexity are governed by the possibility of both upward and downward causation. They account for the possibility of downward causation on the basis of the notion of emergence so that more complex systems can influence less complex systems.

On this basis they call for a unified worldview where what reality is, is related to what it ought to be. They argue that one can also identify a hierarchy of goals at each of the levels of complexity. The higher level goals operate in social systems and are articulated in terms of categories such as intrinsic worth, visions, values and systems of meaning (sensemaking). They say: "Meaning will be found in an overall worldview; values are embodied in the vision put forward for any particular organization, including society as a whole, providing its highest-level goals" (1996:77). Reflection on worthy goals is of course the field of ethics and of theology. 
It should be noted that their notion of a worldview therefore seeks to be consistent with scientific explanations of reality (i.e. in terms of a cosmology), but cannot be reduced to that. In fact, they argue that scientific explanations of reality remain insufficient without the added layers of explanation provided by aesthetics, ethics and theology. A simple physical explanation would be woefully lacking to develop an understanding of the systems of meaning expressed in art, music and literature. They suggest that a worldview can offer such a more complete and coherent explanatory scheme. Ellis and Murphy's own constructive contribution, namely their Anabaptist kenotic ethic based on self-sacrifice and non-violence, need not concern us here. Suffice it to say, that they find such a kenotic ethic operative at all levels of complexity.

It is clear that the focus of this use of the term worldview is on doing justice to insights developed in scientific cosmologies on the one hand but also to particular moral codes on the other hand. Both of these are made highly explicit. The tacit assumptions that are operative in the social construction of reality are not emphasised.

\section{Discourse on African Religion: Laurenti Magesa on African Religion (1997)}

African traditional religion and culture are often contrasted in rather general terms with Western culture and the worldview of modernity in particular. In response, it is typically suggested that one can identify a shared worldview underlying indigenous knowledge systems, despite the obvious language, cultural and religious differences (see Balcomb 2014:81). Magesa suggests that African religion should be considered as a generic whole (1997:14-18). My impression (and here I may be mistaken) is that discourse on such a shared worldview is stronger in the context of central and eastern Africa than it is in southern or western Africa.

What is understood under the term 'worldview' in such a context? Clearly, indigenous knowledge is embedded in such a worldview, but there is no overt attempt to relate such a worldview to contemporary science. Such a worldview cannot be related directly to religion since such a worldview underlies religious differences. Does it have to do with a particular understanding of the relationships between God, humanity and the rest of the world (i.e. in line with Kuyper's use of the term life-system)? This is probably closer to the truth, but still does not do justice to the themes that are explored in relation to an African worldview. These include a cyclical notion of time, the primal vision of a cosmic balance of forces (where there is no dichotomy between the physical and the spiritual so that the physical can serve as a vehicle for the spiritual), the sacrality of land and of life, the distinction between the visible and the invisible world, the sense of human kinship with nature and human participation in an interdependent organic whole (see also Bediako 1995:92-93, Balcomb 2014:50-51). Let us address this question on the basis of Laurenti Magesa's work African Religion: The Moral Traditions of Abundant Life (1997).

Magesa adopts Clifford Geertz's understanding of a worldview in order to make it clear how an ethos is related to both a set of religious symbols and a worldview. Geertz defines a worldview in this way: "Their world-view is their picture of the way things in sheer actuality are, their concept of nature, of self, of society. It contains their most comprehensive ideas of order. Religious belief and ritual confront and mutually confirm one another; the ethos is made intellectually reasonable by being shown to represent a way of life implied by the actual state of affairs which the world-view describes, and the worldview is made emotionally acceptable by being presented as an image of an actual state 
of affairs of which such a way of life is an authentic expression" (quoted by Magesa 1997:3-4).

Magesa's understanding of religion is closely related to this notion of a worldview. Drawing on Hans Küng's work he suggests that religion is a view of life, an approach to life and especially a way of life. It offers a transcendentally grounded and immanently operative system of co-ordinates by which people orientate themselves intellectually, emotionally and existentially (1997:24-25).

On this basis Magesa explores the embeddedness of African moral traditions (understood in terms of 'abundant life') in such a religiously infused view of life and way of life. He uses the term 'moral universe' to capture that (1997:35-76). The question is how the world and humanity's place and role within it is understood in terms of African religion. Magesa suggests that "the universe is a composite of divine, spirit, human, animate and inanimate elements, hierarchically perceived, but directly related and always interacting with each other" (1997:39). One may therefore discern both visible and invisible forces, also called 'vital forces' (Placide Tempels). These mystical powers have to be in balance with each other in order for human communities to flourish (1997:51). Religion is thus understood functionally as a means to help people to acquire life, health, fecundity, wealth and power and to maintain social cohesion and order (1997:51). On this basis Magesa mentions and explores a number of major themes contained in this view of the universe: the sacrality of life, respect for the mystical nature of the world, respect for the human person, a sense of family and community, an emphasis on solidarity, participation as well as sharing through friendship, healing and hospitality. This is only possible if the harmony of forces in the visible and the invisible world is maintained in order to contain evil forces, any breach in relationships and any weakening of the bonds of community. Magesa concludes that "Sustaining the universe by maintaining harmony or balance between its two spheres and among all beings is the most important ethical responsibility for humanity and it forms the basis of any individual's moral character" (1997:73). Without harmony, chaos enters into the universal moral order through greed, selfishness and exploitation (1997:74). In order to resist this, African religion introduces a system of totems, taboos and rituals.

One may conclude that Magesa's use of the term worldview is closely related to the role of religion and the maintenance of the social and moral order. The distinctive features of an African worldview may be understood in terms of the distinction between the visible and the invisible world, the related understanding of causation in terms of vital participation and the particular notion of time associated with that. Western notions of science may help one to understand the visible world but does not fathom the hierarchy of forces and does not account for the impact of the invisible world. They may be able to explain what happens and why it happens but cannot uncover the (invisible) meaning of an event. Here Magesa is not all that far removed from Ellis and Murphy (their notion of hierarchy and the possibility of downward causation) even though he pays basically no attention to science. Unlike John Mbiti, Magesa does not explore a distinctly African notion of temporality, but this may well be where the main difference with Ellis and Murphy lies. The linearity of time is acknowledged in both the Jewish notion of the history of election and the 'arrow of time' recognised in the laws of thermodynamics. By contrast, the African worldview may assume a cyclical, mythical or narrative notion of time. However this is to be understood, the emphasis on the maintenance and restoration of order suggests the possibility of a return to a harmony of visible and invisible life forces within which human beings participate. 


\section{Some Concluding Comments}

My aim in juxtaposing these discourses on the term 'worldview' is not to find common ground between them or to offer definitions for a way forward or even to compare them in any detail. I merely hope to bring some clarity by indicating the distinct discourses in which the term is used in a theological context. This may inhibit the tendency towards isolation and facilitate more cross referencing between these discourses.

One may nevertheless note that each one of these notions of a worldview tends to place the social construction of reality, that is an understanding of a) the structure of human societies and b) its moral landscape, within a larger frame of reference that incorporates c) scientific insights and that can d) indicate the place of humanity within the cosmos and e) whatever may transcend the cosmos. Although all these aspects are usually addressed, some are emphasised more than others within the different discourses that shape the study of religion and theology.

There is a deeper, underlying problem though. This is intertwined with the longstanding inability to relate cosmological notions of time on the basis of the movements of the sun and the stars (already analysed by Aristotle) and the psycho-social experience of the fleeting nature of time (as articulated by Augustine). Ricoeur $(1988,14)$ states this bluntly: "we must ... admit that a psychological theory and a cosmological theory [of time] mutually occlude each other to the extent they imply each other." This underlying problem has not been resolved as yet, also not in theological appropriations of the term worldview. The social construction of reality and scientific reconstructions of that reality remain at odds with each other.

I would suggest that there is no point in adopting a worldview if that becomes a blindfold disabling one to view the world. This is a typical flaw in neo-Calvinist discussions of the concept worldview (see Wolters, 2005). The desire to make Christian beliefs relevant to other spheres of society yields little more than the articulation of a set of reformed doctrines (e. g. on God's sovereignty, the goodness of the created order, the impact of sin and the reign of God). If a Christian worldview is the same as a Christian view of the world, it is best discussed as a theme in systematic theology, namely by redescribing the world as the triune God's own beloved creation. If not, how are sociological and scientific data to be incorporated in a Christian worldview? Clearly, Christian perspectives on the world underdetermine the available data so that such a worldview cannot be derived from biblical principles alone. This was recognised by Herman Bavinck in his Stone lecturers (1908/1909) where he developed the notion of a 'philosophy of revelation' i.e. an attempt by Christians to reflect on the significance of God's whole revelation, including the natural world.

Without an engagement with common human experience and scientific inquiry, this does not by itself offer a view of the world. Instead, it often merely inhibits scientific inquiry. Does it actually help one to see things that would otherwise have been missed? How is this notion of a worldview shaped by scientific data and by social analysis? Or does the religious zeal to transform the world in every square inch of society reveal worldblinkers or even world-blindness instead of a worldview? If the focus is here on viewing the world, it seems that one is invited to look at the viewing instead of at the world.

In his contribution to the volume After Worldview (Bonzo \& Stevens 2009) James Olthuis recognises what is at stake. In criticising his own earlier work, he says: "For even though I relativized a worldview by situating it as a medium always informed and shaped in a two-directional movement between faith commitment and all of the other dimensions of 
human life, a worldview still has too much the feel of a more or less polished instrument, a kind of concrete steel bridge, a pair of glasses that, if kept tightly ground, will allow its wearers to make sense of life, giving definite shape and form to the often murky and confused world of experiences that is reality" (Olthuis 2009:86-87).

I would concur that there is a need for a Christian view of the world that requires such a two-way movement. I would hesitate to describe that as a 'Christian worldview' though. In order to avoid misunderstanding I would prefer to use the term worldview in a descriptive way to indicate the mostly tacit assumptions that groups of people harbour about the world, including their cosmological assumptions. A worldview helps people to make sense of cosmological insights, social structures, moral visions, goals and values, beliefs and religious convictions alike. Accordingly, there can be no one 'biblical' worldview and to label any one worldview as 'Christian' would miss the point. There is not only one Orthodox, Catholic, reformed or Pentecostal worldview either, not even one African Pentecostal worldview. Put cryptically, a Christian way of viewing the world (as God's household) in which one always already participates, is vastly different from a Christian worldview (as understood in neo-Calvinist terms).

There is another side of the coin though. A worldview is not a matter of viewing only. The formation of a worldview is not merely the product of (scientific) observation but always already evolving through participation in a world-in-formation. It may therefore be appropriate to emphasise various ways of being in the world (or world formation) as the context within which any notion of viewing the world (or worldviews) may emerge (see Balcomb 2013:viii). Tim Ingold's formulation is eloquent: "Rather than thinking of ourselves only as observers, picking our way around the objects lying about on the ground of a ready-formed world, we must imagine ourselves in the first place as participants, each immersed within the whole of our being in the currents of a world-in-formation: in the sunlight we see in, the rain we hear in and the wind we feel in. Participation is not opposed to observation but is a condition for it, just as light is a condition for seeing things, sound for hearing them and feeling for touching them" (Ingold 2011:129).

A worldview therefore cannot be based on cosmological insights alone. It entails the social construction of reality from within a particular environmental embeddedness. We do not see the world as it is; we see the world as we are (Rasmussen 2013:76). A worldview not only offers a view of the ordered patterns in the physical world (a cosmology); it also places that within a comprehensive system of meaning that can account for the origin and destiny of the world, the forces that govern it, our human place within it and human questions about meaning, suffering and evil.

Any worldview remains incomplete, broken, distorted, misshapen. It imposes some order and is therefore an exercise in the use and abuse of power. This cannot be avoided. There is only one thing that is worse than adopting a particular worldview - and that is to pretend not to have adopted one at all, to be blind for the assumptions that we make about the world in which we are embedded. 


\section{BIBLIOGRAPHY}

Balcomb, A 2014. Journey into the African Sun: Soundings in search of another way of being in the world. Pretoria: Unisa.

Bavinck, H 1909. The philosophy of revelation. London: Longmans, Green \& Co.

Bavinck, H 1913. Christelijke Wereldbeschouwing, Kampen: JH Kok.

Bediako, K 1995. Christianity in Africa - the renewal of a non-western religion. Edinburgh: Edinburgh University Press.

Berger, PL \& Luckmann, T 1967. The social construction of reality: a treatise in die sociology of knowledge. New York: Penguin Press.

Berger, PL 1967. The sacred canopy: elements of a sociological theory of religion. New York: Doubleday.

Bonzo, JM and Stevens, M (eds.) 2009. After worldview: Christian higher education in postmodern worlds. Sioux Center: Dordt College Press.

Ellis, GFR \& Murphy, N 1996. On the moral nature of the universe. Minneapolis: Fortress Press.

Ingold, T 2011. Being alive: Essays on movement, knowledge and description. London \& New York: Routledge.

Kuyper, A 1931/2007. Lectures on Calvinism. New York: Cosimo Classics.

Magesa, L 1997. African religion: The moral traditions of abundant life. Maryknoll: Orbis Books.

Naugle, D 2009. Worldview: History, theology, implications. In Bonzo, JM and Stevens, M (eds.): After worldview: Christian higher education in postmodern worlds, 5-26. Sioux Center: Dordt College Press.

Olthius, JH 2009. "Where there is love, there is vision": Witnessing in/under/through worldviews. In: Bonzo, JM \& Stevens, M (eds.), After Worldview: Christian Higher Education in Postmodern Worlds, 81-94. Sioux Center: Dordt College Press.

Rasmussen, LL 1994. Cosmology and ethics. In: Tucker, ME \& Grim, JM (eds.): Worldviews and ecology: Religion, philosophy and the environment, 173-180. Maryknoll: Orbis Books.

Rasmussen, LL 2013. Earth honoring faith: Religious ethics in a new key. Oxford: Oxford University Press.

Ricoeur, Paul 1988. Time and Narrative Volume 3. Chicago: University of Chicago Press.

Swimme, B \& Berry, T 1992. The universe story. From the primordial flashing forth to the ecozoic era. New York: Penguin Books.

Toulmin, S 1990. Cosmopolis: The hidden agenda of modernity. New York: The Free Press.

Tucker, ME \& Grim, JM (eds.) 1994. Worldviews and ecology: Religion, philosophy and the environment. Maryknoll: Orbis Books.

Wolters, AM 2005. Creation regained: Biblical basics for a reformational worldview. Grand Rapids: WB Eerdmans. 